\title{
Analysis of Urban Agglomeration in Economic and Legal Perspectives (A Study on the Development of Industrial Agglomeration Areas in Semarang City)
}

\author{
Andi Tri Haryono1, Muhamad Hasan Muaziz², Abdul Kadir Jaelani ${ }^{3}$ \\ ${ }^{1}$ Faculty of Economics, Universitas Wahid Hasyim, Semarang, Indonesia \\ 2 Universitas Nahdlatul Ulama Indonesia, Jakarta, Indonesia \\ ${ }^{3}$ Faculty of Law, Universitas Sebelas Maret, Surakarta, Indonesia
}

Info Artikel
Keywords:
Urban Agglomeration, Agrarian
Law, Semarang.

P-ISSN: 1412-6605
E-ISSN: 2301-6426
Kata kunci:
Urban Aglomerasi, Hukum
Agraria, Semarang.
Corresponding Author:
jaelaniabdulkadir@staff.uns.ac.id

\begin{abstract}
This study tries to analyze the implementation of laws and policies regarding the development of urban agglomerations, analyze agrarian law regulations in Indonesia addressing industrial estate issues, and analyze the leading sectors and economic potential of the city of Semarang. In this study, the authors use the Base Sector Analysis/LQ Analysis, Economic Sector Performance Analysis/Shift Share Analysis, Growth Ratio Model Analysis/GRM, Klassen Typology Analysis, Overlay Techniques, and SWOT Analysis to measure the competitive advantage of each element), and provide policy recommendations for the government as well as for industry players. The object of this research is spread over several industrial areas located in Semarang City including Wijaya Kusuma Industrial Area, Candi Industrial Area, BSB Industrial Park, and Terboyo Industrial Estate. The findings of this study are that it is known that leading sectors such as warehousing, financial services, transportation, retail, real estate, trade, and construction are economic bases that are growing rapidly and can support the development of urban agglomerations.

Abstrak
Penelitian ini mencoba melakukan analisa terhadap aturan
perundang-undangan serta kebijakan terkait urban aglomerasi, selain
itu juga akan melakukan kajian terhadap aturan hukum agraria yang
berkaitan dengan kawasan industri, serta akan melakukan analisa
terhadap potensi ekonomi yang dimiliki oleh Kota Semarang. Dalam
penelitian ini, penulis menggunakan metode Analisis Sektor
Basis/Analisis LQ, Analisis Tipologi Klassen, Teknik Overlay, dan
Analisis SWOT untuk mengukur keunggulan kompetitif masing-
masing unsur. Objek penelitian ini tersebar pada beberapa kawasan
industri yang terletak di Kota Semarang diantaranya Kawasan
Industri Wijaya Kusuma (Persero), Kawasan Industri Candi, Taman
Industri BSB, dan Kawasan Industri Terboyo. Temuan dalam
penelitian ini bahwa terdapat sektor unggulan seperti pergudangan,
jasa keuangan, transportasi, ritel, perumahan, perdagangan, dan jasa
konstruksi yang diketahui mampu mengalami pertumbuhan yang
sangat pesat serta dapat mendukung urban aglomerasi.
\end{abstract}




\section{Introduction}

The Indonesian economy during the pandemic continued to grow positively as shown in the third quarter of 2021 although it slowed down compared to the previous quarter's achievement in 2021, the Indonesian economy grew by $3.51 \%$ (YoY), lower than the previous quarter's achievement of 7.07\% (YoY). The value of Indonesia's exports in October 2021 reached US $\$ 22.03$ billion, an increase of 6.89 percent compared to exports in September 2021. Compared to October 2020, the export value rose by 53.35 percent. ${ }^{1}$ Indonesia recorded a larger trade surplus in July 2021, amounting to USD 2.59 billion compared to USD 1.32 billion in the previous month. It can be concluded that Indonesia's trade balance has remained positive since May 2020. Overall, Indonesia's trade balance for the January-July 2021 period recorded a surplus of USD14.42 billion, far above the surplus of USD8.65 billion in the same period 2020.

The concept of agglomeration will always coincide with the problems that arise behind the development and licensing of location permit areas. After the enactment of Law No. 1 of 1967 concerning Foreign Investment and Law No. 8 of 1968 in Indonesia, the acceleration of the development of industrial estates and location permit areas experienced significant growth. According to data from the United Nations Industrial Development Organization (UNIDO) in 2015 there were 260 industrial estates in Indonesia. Referring to the data published by the Ministry of Industry in 2012, the distribution of industrial estates in Indonesia as a whole is divided into 6 (six) regions consisting of $54.07 \%$ in Java, $33.14 \%$ in Sumatra, $9.30 \%$ are on the island of Kalimantan, $2.33 \%$ are on the island of Sulawesi, $0.58 \%$ are on the islands of Bali and Nusa Tenggara, and $0.58 \%$ are on the islands of Maluku and Papua.

This research is focused on the implementation of laws and policies regarding the development of urban agglomerations, analyzed the agrarian law regulations in Indonesia addressing the issue of industrial estates, as well as analysis of the leading sectors and economic potential of the city of Semarang. This study discussed the contextual analysis of land use in industrial areas using agrarian law analysis and agrarian economics by the concept of agglomeration that leads to growth and sustainability. Meanwhile, the research output to be addressed is to identify the location licensed area in Semarang from the perspective of agrarian law and its economic analysis. In addition, this study also aims to conduct a Feasibility Study (Base Sector Analysis/LQ Analysis, Economic Sector Performance Analysis/Shift Share Analysis, Growth Ratio Model Analysis/GRM, Klassen Typology Analysis, Overlay Techniques, and SWOT Analysis to measure the competitive advantage of each element), as well as

1 Badan Pusat Statistik, ‘Ekspor Oktober 2021 Mencapai US\$22,03 Miliar Dan Impor Oktober 2021 Senilai US\$16,29 Miliar', The Central Bureau of Statistics, 2021 <https://www.bps.go.id/pressrelease/2021/11/15/1828/ekspor-oktober-2021-mencapai-us-22-03-miliardan-impor-oktober-2021-senilai-us-16-29-miliar-.html> [accessed 15 November 2021]. 
providing policy recommendations for the government as well as for industry players. $^{2}$

The object of this research is spread over several industrial areas located in Semarang City including first, the Wijaya Kusuma Industrial Estate (Persero) which is a state-owned enterprise (BUMN). Second, the Candi Industrial Estate, third, the BSB Industrial Park, and the last Fourth, Terboyo Industrial Estate.

This study used analytical discourse research methods and normative juridical, while for the realm of economic studies using a mixed-method research method, namely Base Sector Analysis (LQ Analysis), Growth Ratio Model Analysis (MRP), and Klassen Typology Analysis and SWOT analysis. Respondents in this study consisted of: academics, policymakers (Semarang City Government), industrial area managers, key persons for companies in industrial areas, city observers, and the general public.

\section{Results and Discussion}

\section{Agglomeration and Urban Development}

In the 1980s the term agglomeration began to emerge. One of the pioneers of the idea of Piore and Sabel (1984) emphasizes that an area or region can compete between regions or regions, especially in the context of globalization, market openness, and market expansion in the post-mass-production period. The study identifies an agglomeration structure consisting of a vertical and horizontal network of small and medium-sized enterprises (small and medium-sized enterprises) in flexible specialization and is expected to become a large business sector and be able to become the backbone of the industrial sector in a city. ${ }^{3}$

Several theories try to explore the problem of agglomeration. But before we discuss further these theories, it is necessary to first understand the concept of agglomeration. Agglomeration economies or localized industries, according to Marshal, arise when industry chooses a location for its production activities that allow it to take place in the long term so that people will benefit a lot if they follow the action of establishing a business around that location. ${ }^{4}$

Montgomery 1988 in Kuncoro, 2002 defines agglomeration savings as savings due to the presence of adjacent locations (economies of proximity) associated with the spatial grouping of companies, workers, and consumers to minimize costs such as transportation, information, and communication

2 Mas Pungky, Hendra Wijaya, and Mohammad Zulfikar Ali, 'Legislation Impediments in Reorganising Government Bodies in Indonesia', Jurnal Bestuur, 9.1 (2021), 1-12.

${ }^{3}$ Michael J. Piore and Charles F. Sabel, The Second Industrial Divide (New York: Basic Books, 1984).

${ }^{4}$ John F. McDonald, Fundamentals of Urban Economics (New Jersey: Prentice Hall, 1997). 
costs. ${ }^{5}$ In the context of geographic economics, the concept of agglomeration relates to the spatial concentration of population and economic activities. ${ }^{6}$

Meanwhile, Markusen stated that agglomeration is a location that is "not easy to change" due to external savings that are open to all companies that are located close to other companies and service providers, and not due to the calculations of companies or individual workers. ${ }^{7}$ Furthermore, by referring to some of these definitions, it can be concluded that agglomeration is a spatial concentration of economic activity and population that arises because of the savings obtained due to adjacent locations.

An agglomeration economy is an externality resulting from the geographical proximity of economic activities. Furthermore, the existence of an agglomeration economy can have a positive influence on the rate of economic growth. As a result, areas that are included in agglomeration generally have a higher growth rate than areas that are not agglomerated.

The positive relationship between geographic agglomeration of economic activities and economic growth has been widely demonstrated. 8 Agglomeration produces spatial differences in income levels. The more spatially agglomerated and economy will increase its growth. Areas with many processing industries grow faster than areas with few processing industries. The reason is that regions that have more processing industries have accumulated capital. In other words, areas with a concentration of processing industry grow faster than areas without a concentration of processing industry.

One of the requirements in developing urban agglomerations is a location permit, this is a basic requirement that must be met by a company to obtain land rights, this is as regulated in Article 2 of the Minister of Agrarian Affairs/ Spatial Planning/ BPN No. 5 of 2015 concerning Location Permits. In addition, land control carried out by a company must also be by the Regional Spatial Plan as stipulated in Article 3 of the Minister of Agrarian Affairs/ Spatial Planning/ BPN No. 5 of 2015 concerning Location Permits.

In the effort to obtain a location permit, a company is also required to be able to meet several administrative requirements such as administrative, juridical, technical, managerial, and environmental. ${ }^{9}$ The provisions of Article 20 in conjunction with Article 22 of the Regional Regulation of the City of Semarang No. 8 of 2014 concerning Licensing and Non-Licensing, is one of the

${ }^{5}$ M. Kuncoro, Analisis Spasial Dan Regional: Studi Aglomerasi Dan Kluster Industri Di Indonesia. (Yogyakarta: UPP AMP YKPN, 2002).

${ }^{6}$ Malmberg A. and Maskell P., 'Towards and Explanation of Industry Agglomera- Tion and Regional Spezialitation', Euro- Pean Planning Studies, 5.1 (1997), 25-41.

7 Kuncoro.

8 Martin P. and Ottavianno, 'Growth and Agglomeration', International Economic Review, 42.4 (2001), 947-68.

9 Erlyanto Eko Kurniawan, Rifqi Aditya Halimawan, and Dwi Kurniani, 'Analisis Pengaruh Pengembangan Kawasan Industri Candi Terhadap Banjir Sungai Bringin', Karya Teknik Sipil Journal, 6.1 (2017). 
legal bases that form the basis for the application of licensing for a company that will set up its business in Semarang City. ${ }^{10}$ Location permits for industrial, housing, and infrastructure development areas in Semarang City are not widely studied comprehensively, especially from the point of view of agrarian law and economic analysis approach. ${ }^{11}$

Several studies showing the effect of agglomeration development on economic growth have been shown by several researchers including Martin and Ottaviano (1999), Fujita and Thisse (2002), Crozet and Koeing (2007), and Baldwin and Martin (2004) argue that agglomeration can encourage economic growth. ${ }^{12}$ In looking at the relationship between agglomeration and economic growth, our research has referred to appropriate research, focusing our analysis on urban agglomeration. ${ }^{13}$ Recently, empirical studies have shown that international trade promotes economic growth (Carkovic and Levine $2002 ;^{14}$ Jallab et al. 2008; ${ }^{15}$ and Wijeweera et al. 2010). Study conducted by (Jonhhson 2006; Wijeweera et al. 2010) ${ }^{16}$ showed a positive relationship between the labor force and economic growth. These empirical studies strengthen the theoretical model of endogenous growth. ${ }^{17}$

\section{Overview of Agglomeration Urban Development in Semarang City}

The city of Semarang as the capital city of Central Java Province has a strategic role in encouraging efforts to increase the economy. The Economic Growth Rate (EGR) of Semarang City continues to increase from year to year, in 2018 the LPE of Semarang City reached 6.52\% and in 2019 it reached $6.86 \% .18$ However, the Covid-19 outbreak also had a very large impact on the rate of economic growth, it was recorded that in 2020 the economic growth rate of

${ }^{10}$ Hartono, 'Pembangunan Kawasan Industri Menurut Kajian Hukum Lingkungan. Studi Kasus Kawasan Industri Candi Di Kota Semarang' (Master of Law Thesis, 2007).

${ }^{11}$ Anif RIzqianti Hariz, 'Pengembangan Kawasan Industri Ramah Lingkungan, Studi Kasus Di Taman Industri BSB Semarang', Journal of Biology and Applied Biology, 1 (2018).

${ }^{12}$ P. Martin and G. Ottaviano, 'Growing Localizations: Industry Localization in a Model of Endogenous Growth', European Economic Review, 43.2 (1999), 281-302.

${ }^{13}$ Sala-i-M., D. Xavier, and R. Miller, 'Determinants of Long-Term Growth: A Bayesian Averaging of Classical Estimates (BACE) Approach', American Economic Review, 94.4 (2004), 813-35.

14 Carkovic M. and R. Levine, Does Foreign Direct Investment Accelerate Economic Growth? W/P No. 2 (Minnesota: Department of Business Finance, University of Minnesota, 2002).

${ }^{15}$ Jallab M., Gakou M., and Sandretto R., Foreign Direct Investment Macroeconomic Instability and Economic Growth in MENA Countries, W/P, GATE, UMR 5824 Du CNRS, 2008.

${ }^{16}$ Wijeweera A., Villano R., and Dollery B, Economic Growth and FDI Inflows: A Stochastic Frontier Analysis, W7P. (University of New England, 2010).

${ }_{17}$ M. Romer, 'Growth Based on Increasing Returns Due to Specialization', Journal of Political Economy, 94.5 (1990), 71-102.

${ }^{18}$ Pemerintah Kota Semarang, 'Laju Pertumbuhan Ekonomi Kota Semarang Terus Mengalami Peningkatan', 2020

<https://semarangkota.go.id/p/1729/laju_pertumbuhan_ekonomi_kota_semarang_terus_mengalami_pe ningkatan> [accessed 17 November 2021]. 
Semarang City experienced a slowdown from $6.89 \%$ to minus $1.61 \%$. The slowdown resulted in a sluggish market and an increase in the number of poverties in Semarang City.

Referring to data released by the Semarang City Central Statistics Agency in August 2021, the open unemployment rate was $9.53 \%$, a decrease of $0.04 \%$ when compared to August 2020. Meanwhile. The total workforce in August 2021 was 1.034 million people, an increase of 10,000 people compared to August 2020. However, the Labor Force Participation Rate (TPAK) decreased by 0.47 percentage. ${ }^{19}$ The increase in the economic growth rate of the city of Semarang cannot be separated from the contribution of the industrial sector, even though the position of the industrial area in the city of Semarang is relatively lagging with a fairly low investment value. ${ }^{20}$

The Wijaya Kusuma industrial area is around Rp17.520.000.000 (seventeen billion five hundred and twenty million rupiah), the Jababeka industrial area has an investment value of Rp911.571.749.441 (nine hundred billion), Lippo Cikarang Industrial Estate Rp302.261 million, (three hundred billion) and Rungkut Industrial Estate of Rp61.860.675.454 (sixty billion). Ownership of shares in this industrial area includes: Jababeka owned by Mu'min Ali Gunawan 21.09\%, 7.21\% Islamic Development Bank, 2.94\% Hadi Rahardja, $0.16 \%$ Setiawan Mardjuki, 68.60\%. Lippo Cikarang owned by PT Kemuning 42 $\%$, Masyarakat $46 \%$, dan PT Metropolis Pertinda $11 \%$. Rungkut Industrial owned by oleh Pemprov 50 \%, Pemprov Jatim 24 \% dan Pemkot Surabaya 25 $\%$. Whereas Wijaya Kusuma owned by Pemerintah Pusat 51 \%, Pemprov Jateng 43 \% dan Pemkab CIlacap 8,52 \%. Sumber: Annual Report 4 Kawasan Industri selama 3 tahun (2015, 2016, dan 2017).

The comparison of industrial areas above illustrates that improving the quality of the area in the city of Semarang is essential. In the Semarang City Medium-Term Development Plan 2016-2021, this is in line with Regional Regulation No. 11 of 2007 concerning Amendments to the Semarang Regional Medium-Term Development Plan 2016-2021.

Meanwhile, the development of industrial and warehousing areas is also emphasized in the Semarang City Regional Regulation No. 14 of 2011 concerning RTRWK Semarang. Whereas the improvement of the quality of the industrial area will be carried out in the Genuk District covering an area of 303 ha, the Tugu Industrial Area of 495 ha, the Industrial Estate in Mijen District covering an area of $175 \mathrm{ha}$, and the Tanjung Emas industrial and warehousing area through the development of the Industrial Estate.

19 Badan Pusat Statistik, 'Tingkat Pengangguran Terbuka (TPT) Sebesar 4,99 Persen', 2020 <https://www.bps.go.id/pressrelease/2020/05/05/1672/februari-2020--tingkat-pengangguran-terbuka-tpt--sebesar-4-99-persen.html> [accessed 25 August 2020].

20 Nur Putri Hidayah, Quincy R Cloet, and David Pradhan, 'The Implementation of Labor Development Principles According to Job Creation Law as a Reason to Protect Wages Rights', Bestuur, 9.1 (2021), 68-76. 
One of the largest industrial estates in the city of Semarang is the Wijaya Kusuma Industrial Estate with the composition of shareholders: the Government of the Republic of Indonesia 51.09\%, Central Java Regional I Level I 40.39\%, and Cilacap Regional Government 8.52\%. Currently, 102 hectares have been matured, and are inhabited by 63 investors (15 PMA and 48 PMDN). Development in progress covers an area of 100 hectares and has completed an area of 40 hectares. The Wijaya Kusuma Industrial Estate allows investors to take advantage of plots according to the type of industry from 2,000 m2 to 50,000 m2. However, the Semarang City Government also needs to increase the capacity of the industrial sector located in other industrial areas such as the BSB Industrial Area, Terboyo, Lami Citra, and the Candi Industrial Area.

\section{Implementation of Public Facilities and Social Facilities in Industrial Estates}

The Industrial estates are strategic assets that have a role in increasing the economic growth of a region, if referring to the definition of industrial estates, it can be interpreted as an area as a place of concentration of industrial activities which is equipped with various facilities and infrastructure to support industrial activities, therefore the continuity of industrial activities carried out by the company can run well. Based on the information provided by the National Industrial Zoning Committee's (USA) 1967, it defines an industrial park / industrial park as an industrial area on a fairly large area of land, which is administratively controlled by a person or an institution that is suitable for industrial activities, due to its location, topography, proper zoning, availability of all infrastructure (utilities), and ease of transportation and accessibility. ${ }^{21}$ In addition, based on The Regulation of the Minister of Industry of the Republic of Indonesia Number: 35/M-IND/PER/3/2010 concerning Technical Guidelines for Industrial Estates an industrial estate is an area where industrial activities are concentrated, equipped with supporting facilities and infrastructure developed and managed by an industrial estate company that already has an industrial estate business permit. ${ }^{22}$

Based on The Government Regulation of the Republic of Indonesia Number 24 of 2009 concerning Industrial Estates, urban agglomeration development is one of the pillars of national economic development, which is directed by applying the principles of sustainable industrial development based on aspects of economic, social, and environmental issues. Therefore, in the development of industrial estates, spatial planning aspects are needed,

${ }^{21}$ National Industrial Zoning Committee's (NIZC), Industrial Zone (USA: National Industrial Zoning Committee's, 1967).

22 Utkarsh K. Mishra and Abhishek Negi, 'Should Trade Remedies Be Eliminated from WTO: A Response to Tania Voon', Journal of Human Rights, Culture and Legal System, 1.3 (2021).

Andi Tri Haryono et.al.: Analysis of Urban Agglomeration..... 
which can synergies planning, infrastructure, and supporting facilities such as the provision of electrical energy, telecommunications, road facilities, and other public facilities. ${ }^{23}$ To achieve this, in developing industrial estates, sustainable and integrated principles are needed so that the industrial area to be built can become a mature and independent area, which is the suitability of spatial planning, availability of facilities and infrastructure, environmental friendliness, efficiency, and security and comfort in doing business.

First, the principle of spatial suitability, in this case, the industrial estate development plan must refer to the spatial plan issued by the regional government. Second, the principle of the availability of infrastructure and facilities, in this case, to fulfill this principle, several factors must be met, namely:

a. Availability of road access that can meet the smooth flow of transportation for industrial activities;

b. Availability of energy sources capable of meeting the needs of industrial activities in terms of availability, quality, quantity, and certainty of supply;

c. Availability of water sources as industrial raw water, either sourced from residential water, Local Water Company, or deep groundwater;

d. Availability of telecommunications systems and networks for telephone and data communication needs;

e. Availability of other supporting facilities such as management offices, firefighting units, banks, post offices, polyclinics, canteens, religious facilities, industrial employee housing, security posts, sports/physical fitness facilities, public transport stops, and other supporting facilities as needed.

Third, the industrial area plan to be built must be friendly to the environment, therefore in the effort to develop an industrial area it is required to complete an Environmental Impact Analysis document as a basic document that must be included, the Environmental Impact Analysis document is important in every industrial estate development plan. Which has the function of providing input in making every decision, as an effort to prevent, control and monitor environmental impacts that occur as a result of the development of industrial estates. With the completion of the Environmental Impact Analysis document, it will certainly provide benefits for the development and sustainability of industrial estates, namely knowing the positive and negative impacts of industrial estate development project activities, saving on the use

${ }^{23}$ Mishra and Negi. 
of natural resources and with the Environmental Impact Analysis document, it will be easier to get loans from banks.

Fourth, the principle of efficiency, which is a principle related to the governance system established by the developer/manager of industrial estates to make it easier for investors or users of industrial estate services to have an impact on the ease of the licensing process, development, and availability of facilities and infrastructure for area development. Fifth, the principle of safety and comfort in business. Therefore, a guarantee from the government is needed to maintain political stability, economy, security, and comfort in doing business.

These five principles mentioned above, need to be sustainable and integrated so that industrial estate development becomes a pillar of economic growth. In addition, from a global perspective, the existence of industrial estates has a fairly broad impact where economic development through industry can bring about very basic changes in the country's economic structure originating from the industrial sector. ${ }^{24}$

In addition to the five principles described above, several other considerations affect the development of an industrial area, namely: First, the distance between the industrial area and the city center, this relates to public service facilities that can be obtained by industrial areas such as markets, hospitals, electricity, clean water, road facilities, banking, and office centers.

Second, the distance between the industrial area and settlements has a positive impact on the fulfillment of housing and the needs of Human Resources (employees), in addition to the development of industrial areas, of course, has an impact on the need for residential areas that are close together and have strategic access to the industrial area. This is a result of urbanization and the movement of people working in industrial areas. However, it is necessary to further understand that industrial estates also have an impact on the environment, this is related to industrial waste generated from the production process

Third, an adequate road network. The road network is something that cannot be ruled out, where industrial estates need adequate and integrated road facilities as a basic means of movement mobility and the level of achievement (accessibility) both in the supply of raw goods, mobility of human resources, as well as the distribution of goods and services from industrial estates.

Availability of the road must take into account the capacity and number of vehicles that will cross the road, in addition to the number of tonnage vehicles that will pass and the condition of the road body and the influence of natural conditions are also taken into consideration. For the development of

${ }^{24}$ Andreas Rasu, ‘Dampak Industri PT Global Coconut Terhadap Masyarakat Di Desa Radey Kecamatan Tenga, Kabupaten Minahasa Selatan’, Jurnal Agri Sosio Ekonomi, 13.1 (2017), 100. 
industrial estates, the road conditions, as well as traffic characteristics and the distance between ports, terminals, and airports, are also considerations that must be considered. Fourth, facilities and infrastructure consist of electricity networks, telecommunications networks, seaports, water availability, both groundwater, and local water company. ${ }^{25}$

\section{The context of Indonesian Agrarian Law and Issues Regarding Industrial Estates}

The land is the main basis of development for both public and industrial purposes, therefore every development cannot be separated from the agrarian aspect, including the use of land and the various challenges in it. Land acquisition is one of the most common aspects that often becomes an obstacle in efforts to develop and grow the economy. Related to land acquisition, it has been regulated in Presidential Regulation no. 36 of 2005 concerning Land Procurement for the Implementation of Development in the Public Interest, Article 1 point 6 explains that "Releasing or surrendering land rights is an activity to release the legal relationship between the holder of land rights and the land they control by providing compensation based on deliberation".

For the government and investors, the selection of areas for the development plan of a location-licensed area is very important considering the location chosen will influence the continuity of the business that will be built in the future. Sriyadi further stated that related to the industrial area to be built, there are at least a few things that need to be considered, namely the area in general, related to this there are at least 5 things that need to be considered including a) close to the market; b) close to the source of raw materials; c) availability of transportation facilities; d) good public services such as water, electricity, and supporting facilities for regional connectivity. ${ }^{26}$

Moreover, the existence of industrial areas is expected to accelerate the spread and even distribution of industrial development. Able to increase efforts to develop an environmentally sound Industry, increase investment competitiveness and Industry competitiveness and provide location certainty according to spatial planning, this is as regulated in Article 2 Paragraph (2) of Government Regulation Number 142 of 2015 concerning Industrial Estates. Based on Article 8 of the Regulation of the State Minister of Agrarian Affairs/Head of the National Land Agency Number 2 of 1999 concerning Location Permits, it is clearly stated that the holder of a location permit is granted the following rights and obligations:

${ }^{25}$ Devi Triasari, 'Right to Sanitation: Case Study of Indonesia', Journal of Human Rights, Culture and Legal System, 1.3 (2021).

${ }^{26}$ Sriyadi, Bisnis Pengantar Ilmu Ekonomi Perusahaan Modern (Semarang: IKIP Semarang, 1991). 
a. Location Permit holders are permitted to free land within the Location Permit area from the rights and interests of other parties based on an agreement with the right holder or parties who have such interests by way of buying and selling, providing compensation, land consolidation, or other means by applicable regulations.

b. Before the land in question is released by the holder of a Location Permit by the provisions in paragraph (1), then all existing rights or interests of other parties on the land in question are not reduced and are still recognized, including the authority which according to law belongs to the holder of land rights. to obtain proof of rights (certificates), and the authority to use and utilize the land for personal or business purposes by the applicable spatial plan, as well as the authority to transfer it to another party.

c. The Location Permit holder is obliged to respect the interests of other parties on the land that has not been acquired as referred to in paragraph (1), not to close or reduce the accessibility of the community around the location, and to maintain and protect the public interest.

d. After the land in question is freed from other rights and interests, the holder of a Location Permit may be granted land rights which authorizes him to use the land by the need to carry out his investment plan.

The process of land acquisition which has a large enough area is certainly different from land that has a small area, one of the things that distinguish it is related to the money/capital that must be prepared by the company, and it is also related to the potential for price manipulation by certain elements. Extensive land acquisition certainly requires large capital, this is certainly an obstacle if the funds owned by the company are limited, while land acquisition carried out in stages has the potential to increase land prices, especially if the land is in a strategic location. The soaring land price is quite reasonable because the landowner will assume that the location adjacent to the planned construction of a factory or industrial area will certainly be crowded with industrial activities, so that it can be used as business land, in addition to land that the owner does not have. Intention to sell so that it becomes an obstacle in land acquisition efforts. On the other hand, the increase in the Sales Value of Tax Objects is also one of the obstacles that must be taken into account for 
industrial estate entrepreneurs, this is because the price of land around industrial estates will also rise quite high from year to year. ${ }^{27}$

\section{Prospects and Challenges of industrial agglomeration areas in Semarang City}

Urban agglomeration development in Semarang City in the perspective of agrarian law, of course, cannot be separated from the financial sector and economic potential in Semarang City. In this study, researchers used at least 4 (four) analytical methods to obtain precise and maximum results, namely Base Sector Analysis (LQ Analysis), Growth Ratio Model Analysis (GRM), Klassen Typology Analysis, and SWOT analysis.

\section{Base Sector Analysis (LQ Analysis)}

The analysis of the LQ calculation is based on the theory of the economic base which is used to determine the basic and non-basic economic sectors in a region. To find out what the basis and non-base sectors are in the city of Semarang, it can be known by looking for the LQ value using the GDP data of the city of Semarang and the province of Central Java in 2010 based on constant prices, then translated into economic sectors to reflect real income and production in the city. Semarang. For the calculation of Location Quotient (LQ) the following formula is as follows (Tarigan, 2005: 82):

$\mathrm{LQ} \quad=\quad \mathrm{V}_{1} \mathrm{R} / \mathrm{V}^{\mathrm{R}}$
$\mathrm{V}_{1} / \mathrm{V}$

$\mathrm{V}_{1} \mathrm{R} \quad$ : Total of Gross regional domestic product (GRDP) per sector in City/Region

VR : Total of Gross regional domestic product (GRDP) all sectors in City/Region

$\mathrm{V}_{1} \quad$ : Total of Gross regional domestic product (GRDP) per sector in Province

V : Total of Gross regional domestic product (GRDP) all sectors in Province

If $L Q>1$, it means that the district level of specialization is higher than the provincial level. On the other hand, if $L Q<1$, the role of the sector in the district is smaller than the role of the sector in the province. LQ $>1$ indicates that the role of the analyzed sector is quite prominent in the area and is often an indication that the area has a surplus of the sector's products and exports it

27 Siti Rahma Novikasari, Duc Quang Ly, and Kerry Gershaneck, 'Taxing Micro, Small and Medium Enterprises in Yogyakarta: Regulation and Compliance', Bestuur, 9.1 (2021), 43-52. 
to other regions. These regions may only export products to other regions or abroad because they can produce these products cheaper or more efficiently. On this basis, $\mathrm{LQ}>1$ indirectly indicates that the region has a comparative advantage for the sector in question.

Using LQ as an indication of the existence of comparative advantage can be used for sectors that have been developing for a long time, while for sectors that are new or growing, especially those that have never existed, LQ cannot be used because the total product does not describe the real capacity of the area. LQ analysis can use various variables such as employment opportunities, GRDP, and the labor sector.

Table 2.1 Location Quotient tahun 2016-2019 Based on 2010 Constant Price GRDP

\begin{tabular}{|c|c|c|c|c|c|c|}
\hline \multirow[b]{2}{*}{ No } & \multirow[b]{2}{*}{ Business Field } & \multicolumn{5}{|c|}{ LQ } \\
\hline & & 2016 & 2017 & 2018 & 2019 & $\begin{array}{l}\text { Average } \\
\text { of LQ }\end{array}$ \\
\hline 1 & $\begin{array}{l}\text { Agriculture, Forestry and } \\
\text { Fisheries }\end{array}$ & 0,074 & 0,072 & 0,071 & 0,059 & 0,069 \\
\hline 2 & Mining and excavation & 0,104 & 0,093 & 0,071 & 0,045 & 0,078 \\
\hline 3 & Processing Industry & 0,866 & 0,860 & 0,856 & 0,765 & 0,837 \\
\hline 4 & Electricity and water supply & 1,277 & 1,248 & 1,320 & 1,229 & 1,268 \\
\hline 5 & Clean Water Supply & 1,527 & 1,487 & 1,464 & 1,307 & 1,446 \\
\hline 6 & Construction & 2,974 & 2,905 & 2,857 & 2,552 & 2,822 \\
\hline 7 & $\begin{array}{l}\text { Wholesale and retail trade, } \\
\text { repair and maintenance of cars } \\
\text { and motorcycles }\end{array}$ & 1,192 & 1,162 & 1,139 & 1,050 & 1,136 \\
\hline 8 & Transportation and trade & 1,379 & 1,080 & 1,341 & 1,168 & 1,242 \\
\hline 9 & $\begin{array}{l}\text { Food and drink accommodation } \\
\text { provider }\end{array}$ & 1,264 & 1,217 & 1,197 & 1,141 & 1,205 \\
\hline 10 & $\begin{array}{l}\text { Information and } \\
\text { Communication }\end{array}$ & 2,628 & 2,574 & 2,533 & 2,340 & 2,519 \\
\hline 11 & Financial Services & 1,754 & 1,723 & 1,702 & 1,521 & 1,675 \\
\hline 12 & Real Estate & 1,868 & 1,828 & 1,791 & 1,866 & 1,838 \\
\hline 13 & Company Services & 2,009 & 1,972 & 1,942 & 1,759 & 1,920 \\
\hline 14 & $\begin{array}{l}\text { Government Administration, } \\
\text { Defense }\end{array}$ & 1,301 & 1,270 & 1,235 & 1,091 & 1,224 \\
\hline 15 & Education Services & 0,741 & 0,725 & 0,834 & 0,694 & 0,748 \\
\hline 16 & $\begin{array}{l}\text { Health Services and Social } \\
\text { Activities }\end{array}$ & 1,017 & 0,999 & 0,981 & 0,990 & 0,997 \\
\hline 17 & Others & 0,730 & 0,772 & 0,716 & 0,760 & 0,744 \\
\hline
\end{tabular}

Source: Analysis Results of the Drafting Team, 2020 
The LQ calculation in the table above has been adjusted to various variables according to the type of business field, which consists of 17 types of business fields according to the Central Java Province GRDP report and also Semarang City GRDP from 2014 to 2017. Following:

Table 2.2 Average Location Quotient Score Based on 2010 Constant Price GRDP

\begin{tabular}{|c|c|c|c|}
\hline Sector & $\begin{array}{l}\text { Average LQ } \\
\text { Value }\end{array}$ & Description & Notation \\
\hline 1. Agriculture, Forestry and Fisheries & 0,069 & Non basis & \\
\hline 2. Mining and excavation & 0,078 & Non basis & \\
\hline 3. Processing Industry & 0,837 & Non basis & \\
\hline 4. Electricity and water supply & 1,268 & Basis & + \\
\hline 5. Clean Water Supply & 1,446 & Basis & + \\
\hline 6. Construction & 2,822 & Basis & + \\
\hline $\begin{array}{l}\text { 7. Wholesale and retail trade, repair and } \\
\text { maintenance of cars and motorcycles }\end{array}$ & 1,136 & Basis & + \\
\hline 8. Transportation and trade & 1,242 & Basis & + \\
\hline $\begin{array}{l}\text { 9. Food and drink accommodation } \\
\text { provider }\end{array}$ & 1,205 & Basis & + \\
\hline 10. Information and Communication & 2,519 & Basis & + \\
\hline 11. Financial Services & 1,675 & Basis & + \\
\hline 12. Real Estate & 1,838 & Basis & + \\
\hline 13. Company Services & 1,920 & Basis & + \\
\hline 14. Government Administration, Defense & 1,224 & Basis & + \\
\hline 15. Education Services & 0,748 & Non basis & \\
\hline 16. Health Services and Social Activities & 0,997 & Non basis & \\
\hline 17. Others & 0,744 & Non basis & \\
\hline
\end{tabular}

Source: Analysis Results of the Drafting Team, 2020

The conclusion from the LQ analysis above is that basically, the economic potential of Semarang City is still very potential to grow and develop. Of the 17 (seventeen) sectors mentioned above, the results show that there are 11 (eleven) sectors that are the base sector and there are 6 (six) non-base sectors. The largest supporting base sector is the construction sector with an LQ value of 2.822, followed by the information and communication sector with an LQ value of 2.519. Meanwhile, the non-basic sector consists of 1) agriculture, forestry, and fishery sectors, 2) mining and quarrying sector, 3) manufacturing 
industry sector, 4) education services sector, 5) health services sector and 6) other service sectors.

Based on data from Development Planning Agency at Sub-National Level (BAPPEDA) Semarang City, the area of Green Open Space is only about 2,739 ha. On the one hand, the data presented by the Department of Hygiene and Parks of Semarang City, shows that the number of city parks is only 188 with a total area of $18.69 \mathrm{Ha}$ and 11 TPUs covering an area of $46.35 \mathrm{Ha}$ with a total green open space area of $65.04 \mathrm{Ha}$. Meanwhile, based on the Decree of the Mayor of Semarang No. 522/410 In 2012, there were 13 urban forests covering an area of $124.15 \mathrm{Ha}$ (only $50 \%$ of the stipulated area was realized). Therefore, it is necessary to add an urban forest area of 4 hectares, therefore the forestry sector cannot make a significant contribution to the GRDP of Semarang City.

\section{Growth Ratio Model (GRM) Analysis}

GRM analysis is useful in regional development planning (Yuuha and Cahyono, 2013). GRM analysis is carried out by comparing the growth of activity in an area to a larger area, both on a large and small scale. In this analysis, there are two growth ratios that can be calculated, namely: the growth ratio of the study/analysis area and the growth ratio of the reference area. $^{28}$

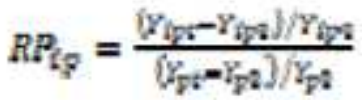

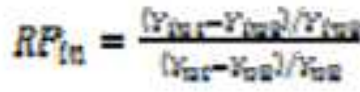

The following graph is the result of the analysis of the Semarang City Growth Ratio Model (GRM) in 2019.

${ }_{28}$ Maulana Yusuf, 'Model Rasio Pertumbuhan (MRP) Sebagai Salah Satu Alat Analisis Alternatif Dalam Perencanaan Wilayah Dan Kota Aplikasi Model: Wilayah Bangka-Belitung', Ekonomi Dan Keuangan Indonesias, 47.2 (1999). 


\section{Graphic 2.1 Growth Ratio Model}

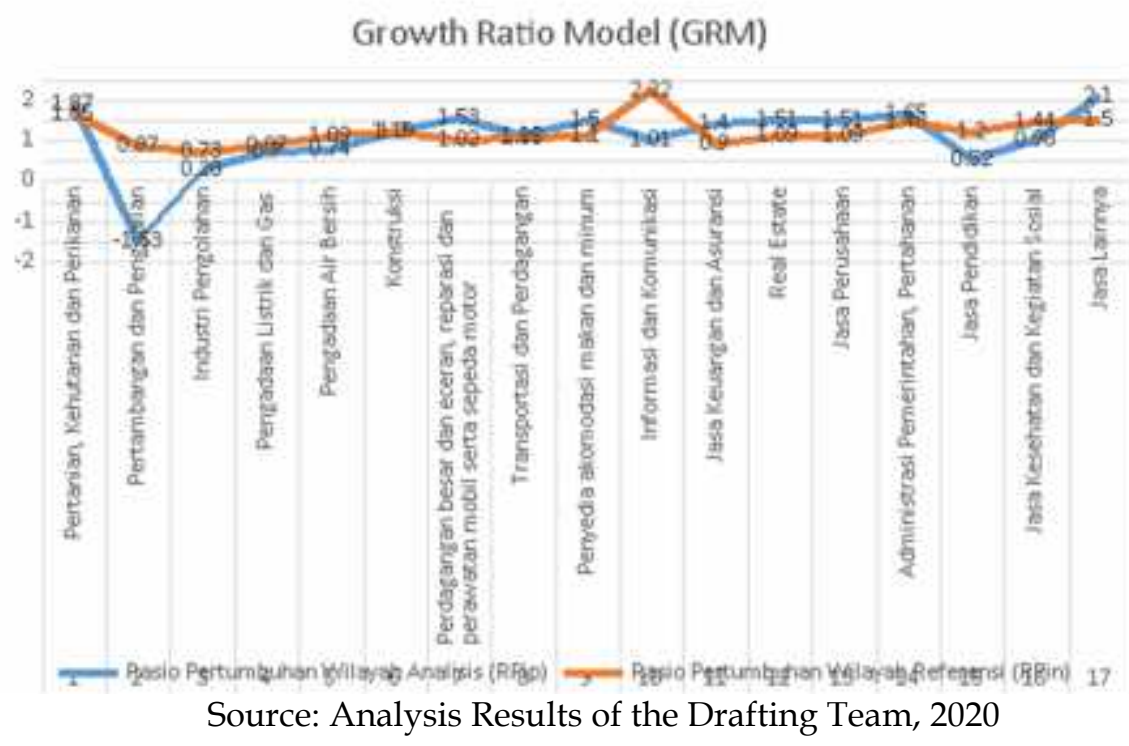

By looking at the table above, it can be concluded that the business sectors such as agriculture, construction, wholesale and retail trade, repair and maintenance of cars and motorcycles, transportation and trade, food and drink accommodation providers, information and communication, real estate, services companies, government administration, and defense, as well as other services are the leading sectors that are able to contribute to the GRDP of Semarang City.

\section{Klassen Typological Analysis}

The Klassen Typology analysis was conducted by comparing the growth rate and contribution of GRDP for each category of business field in the analysis area (Semarang City) with the reference area (Central Java Province). The following are the results of the Klassen Typology analysis. Klassen analysis is used to determine the typology of the pattern and structure of economic growth in each region, in this case, it is used to measure the typology of growth in the city of Semarang.

Klassen's Typological Analysis produced four typologies with the following characteristics: ${ }^{29}$

a. An advanced and rapidly growing sector (Quadrant / KW I)

b. This quadrant shows which business categories in Semarang City have a growth rate and contribution value greater than Central Java Province in the same category.

c. Advanced sector but depressed growth (Quadrant / KW II)

${ }^{29}$ Sjafrizal, Ekonomi Regional, Teori Dan Aplikasi (Padang: Baduose Media, 2008). 
d. This quadrant shows which business field categories in Semarang City have a smaller growth rate but the contribution value of the sector is greater than Central Java Province in the same category.

e. Potential sector and still developing (Quadrant / KW III)

f. This quadrant shows which business field categories in Semarang City have a higher growth rate but the sector contribution value is smaller than Central Java Province in the same category.

g. Not a potential and lagging sector (Quadrant / KW IV)

h. This quadrant shows which business field categories in Semarang City have a growth rate and contribution value that is smaller than Central Java Province in the same category.

The data used in the Klassen Typology analysis is GRDP data at constant prices and GRDP at current prices (without categories $\mathrm{A}, \mathrm{O}, \mathrm{T}$ ) for the last two years, namely 2016 and 2017 in Semarang City and Central Java Province. LQ analysis used data on the number of workers absorbed as a result of SE 2016, GRM uses GRDP data, namely the growth criteria, while Klassen uses both growth and sectorial contributions to GRDP data in Semarang City and Central Java Province. To identify leading sector activities and potentials, both in terms of employment ratio, contribution side, and economic growth side, the analysis of LQ, GRM, and Klassen Typology is combined which is called overlay. ${ }^{30}$

Through the overlay technique, it can be determined which categories of business fields are included in the leading sector, the potential sector, and not both with the following conditions:

a. Declared as a leading sector if the business field category is a leading category by 3 analytical tools. In the Overlay technique it is given a positive notation,

b. It is declared as a potential sector if the category of business field is declared as a leading category by 1 or 2 analytical tools.

c. Not a leading sector or potential if it does not meet criteria 1 or 2 .

Based on the Klassen Typology analysis of the City of Semarang based on the GRDP of the City of Semarang and the GRDP of Central Java in 2016-2017. For more details, see the following graph:

30 Nudiatulhuda Mangun, 'Analisis Potensi Ekonomi Kabupaten Dan Kota Di Propinsi Sulawesi Tengah' (Universitas Diponegoro, 2007). 


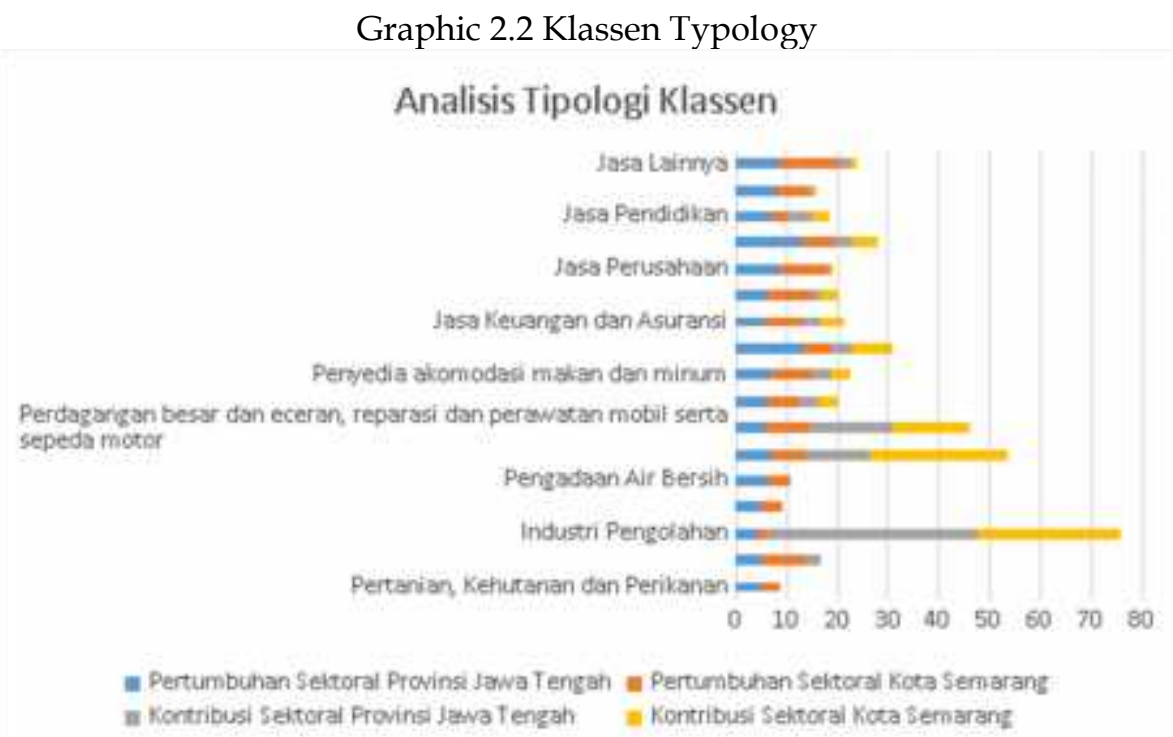

Source: Analysis Results of the Drafting Team, 2020

The results of the Klassen Typology analysis in the table above show that the categories of transportation, warehousing, financial and insurance services, real estate, corporate and professional services are included in the advanced and rapidly growing sectors in Quadrant 1 (one). These results can be interpreted that the four categories in the city of Semarang is a category whose growth rate and contribution value to the total GRDP is greater than that of Central Java Province.

Furthermore, for the categories of Agriculture, Forestry and Fisheries, Electricity and Gas Procurement, Clean Water Procurement, and construction business sectors, including those that are developed but growth is depressed, they are in Quadrant 2 (two). It can be interpreted that the three categories in Semarang City have a greater contribution value but the growth rate is smaller than Central Java Province.

Meanwhile, mining and quarrying business, wholesale and retail trade, repair and maintenance of cars and motorcycles, and other services are included in quadrant 3 (three) criteria. This means that this category in Semarang City has a smaller contribution value but the growth rate is greater than that of Central Java Province.

The other four categories are included in Quadrant 4, which are not potential and underdeveloped sectors. It can be interpreted that this category in Semarang City is a category whose growth rate and contribution value to total GRDP is smaller than that of Central Java Province. The category of business fields included in Quadrants 1,2 and 3 is the leading category based on the results of the Klassen Typology analysis because there is still potential to develop with the attention of the Semarang City Government. 


\section{SWOT analysis}

In determining the position of the SWOT quadrant quantitatively based on EFAS and IFAS calculations, the author refers to the theory developed by Pearce and Robinson (2008) in order to know the real position of the organization. The calculation is done by subtracting the total number of factors $S$ with $W(d)$ and factors $O$ with $T(e)$; The score $(\mathrm{d}=\mathrm{x})$ is then divided by 2 into values or points on the $X$ axis, while the score $(e=y)$ is then divided by 2 into values or points on the $\mathrm{Y}$ axis. In our SWOT analysis, the research team has divided the indicators SWOT indicators as many as 57 indicators that are measured. Based on the results obtained from the internal and external analysis in the table as written above, the results can be summarized as follows: Total Strength Score $=3.51$, Score, Total Weakness $=3.48$, Total Opportunity Score $=3.53$ and Score Total Threat $=3.51$.

From the calculation of the EFAS and IFAS data above, it is known that the coordinates of the TPKS positions in the SWOT quadrant are as follows:

Point $\mathrm{D}$ on the $\mathrm{X}$-axis $=(3,51-3.48) / 2=1.77$
Point $\mathrm{E}$ on the $\mathrm{Y}$-axis $=(3.53-3,51) / 2=1.78$

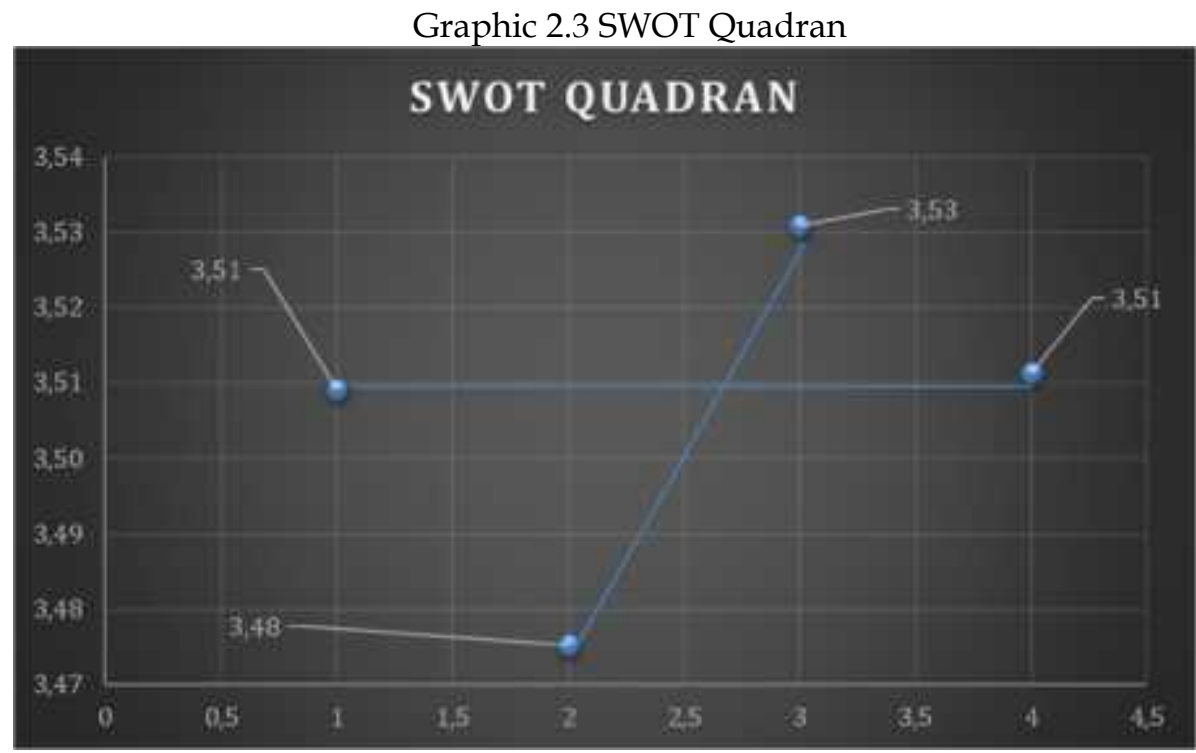

Source: Analysis Results of the Drafting Team, 2020

\section{Conclusion}

The city of Semarang with the status of the capital city of the province of Central Java and has a large industrial area has a large enough impact on urban agglomeration. From the industrial sector, the occurrence of urban agglomeration in the city of Semarang is supported by the many industrial areas 
that have a direct or indirect relationship with the micro-economic base of the community around the area. This can be proven by the level of urbanization and population density in Semarang City, based on BPS 2019 data, the population density of Semarang City reached 4,855 people per square kilometer. This figure will become a new economic strength if it can be managed properly, especially by maximizing various sectors (basic and non-basic).

Although the economic potential of the city of Semarang is very high, the spatial problem for the green open space of the city of Semarang is still far from ideal, this can be seen from the data submitted by the Department of Housing and Settlements of the City of Semarang which states that the green open space in the city of Semarang in 2021 it has only reached $15 \%$ of the provisions contained in the agrarian law which states that green open space is at least $30 \%$. The adequacy of green open space in the city of Semarang is the responsibility of both the government and the people of the city of Semarang in general, which is currently still homework that must be realized, especially in industrial areas and other essential areas.

\section{Refrences}

A., Malmberg, and Maskell P., 'Towards and Explanation of Industry Agglomera- Tion and Regional Spezialitation', Euro- Pean Planning Studies, 5.1 (1997), 25-41

A., Wijeweera, Villano R., and Dollery B, Economic Growth and FDI Inflows: A Stochastic Frontier Analysis, W7P. (University of New England, 2010)

Badan Pusat Statistik, 'Ekspor Oktober 2021 Mencapai US\$22,03 Miliar Dan Impor Oktober 2021 Senilai US\$16,29 Miliar', The Central Bureau of Statistics, 2021 <https://www.bps.go.id/pressrelease/2021/11/15/1828/eksporoktober-2021-mencapai-us-22-03-miliar-dan-impor-oktober-2021-senilai-us16-29-miliar-.html> [accessed 15 November 2021]

- - -, 'Tingkat Pengangguran Terbuka (TPT) Sebesar 4,99 Persen', 2020 <https://www.bps.go.id/pressrelease/2020/05/05/1672/februari-2020-tingkat-pengangguran-terbuka--tpt--sebesar-4-99-persen.html> [accessed 25 August 2020]

Hariz, Anif RIzqianti, 'Pengembangan Kawasan Industri Ramah Lingkungan, Studi Kasus Di Taman Industri BSB Semarang', Journal of Biology and Applied Biology, 1 (2018)

Hartono, 'Pembangunan Kawasan Industri Menurut Kajian Hukum Lingkungan. Studi Kasus Kawasan Industri Candi Di Kota Semarang' (Master of Law Thesis, 2007)

Hidayah, Nur Putri, Quincy R Cloet, and David Pradhan, 'The Implementation of Labor Development Principles According to Job Creation Law as a Reason to Protect Wages Rights', Bestuur, 9.1 (2021), 68-76 
Kuncoro, M., Analisis Spasial Dan Regional: Studi Aglomerasi Dan Kluster Industri Di Indonesia. (Yogyakarta: UPP AMP YKPN, 2002)

Kurniawan, Erlyanto Eko, Rifqi Aditya Halimawan, and Dwi Kurniani, 'Analisis Pengaruh Pengembangan Kawasan Industri Candi Terhadap Banjir Sungai Bringin', Karya Teknik Sipil Journal, 6.1 (2017)

M., Carkovic, and R. Levine, Does Foreign Direct Investment Accelerate Economic Growth? W/P No. 2 (Minnesota: Department of Business Finance, University of Minnesota, 2002)

M., Jallab, Gakou M., and Sandretto R., Foreign Direct Investment Macroeconomic Instability and Economic Growth in MENA Countries, W/P, GATE, UMR 5824 Du CNRS, 2008

Mangun, Nudiatulhuda, 'Analisis Potensi Ekonomi Kabupaten Dan Kota Di Propinsi Sulawesi Tengah' (Universitas Diponegoro, 2007)

Martin, P., and G. Ottaviano, 'Growing Localizations: Industry Localization in a Model of Endogenous Growth', European Economic Review, 43.2 (1999), 281302

McDonald, John F., Fundamentals of Urban Economics (New Jersey: Prentice Hall, 1997)

Mishra, Utkarsh K., and Abhishek Negi, 'Should Trade Remedies Be Eliminated from WTO: A Response to Tania Voon', Journal of Human Rights, Culture and Legal System, 1.3 (2021)

National Industrial Zoning Committee's (NIZC), Industrial Zone (USA: National Industrial Zoning Committee's, 1967)

Novikasari, Siti Rahma, Duc Quang Ly, and Kerry Gershaneck, 'Taxing Micro, Small and Medium Enterprises in Yogyakarta: Regulation and Compliance', Bestuur, 9.1 (2021), 43-52

P., Martin, and Ottavianno, 'Growth and Agglomeration', International Economic Review, 42.4 (2001), 947-68

Pemerintah Kota Semarang, 'Laju Pertumbuhan Ekonomi Kota Semarang Terus Mengalami Peningkatan',

2020 <https://semarangkota.go.id/p/1729/laju_pertumbuhan_ekonomi_kota_ semarang_terus_mengalami_peningkatan> [accessed 17 November 2021]

Piore, Michael J., and Charles F. Sabel, The Second Industrial Divide (New York: Basic Books, 1984)

Pungky, Mas, Hendra Wijaya, and Mohammad Zulfikar Ali, 'Legislation Impediments in Reorganising Government Bodies in Indonesia', Jurnal Bestuur, 9.1 (2021), 1-12

Rasu, Andreas, 'Dampak Industri PT Global Coconut Terhadap Masyarakat Di Desa Radey Kecamatan Tenga, Kabupaten Minahasa Selatan', Jurnal Agri Sosio Ekonomi, 13.1 (2017), 100

Romer, M., 'Growth Based on Increasing Returns Due to Specialization', Journal of Political Economy, 94.5 (1990), 71-102 
Sala-i-M., D. Xavier, and R. Miller, 'Determinants of Long-Term Growth: A Bayesian Averaging of Classical Estimates (BACE) Approach', American Economic Review, 94.4 (2004), 813-35

Sjafrizal, Ekonomi Regional, Teori Dan Aplikasi (Padang: Baduose Media, 2008)

Sriyadi, Bisnis Pengantar Ilmu Ekonomi Perusahaan Modern (Semarang: IKIP Semarang, 1991)

Triasari, Devi, 'Right to Sanitation: Case Study of Indonesia', Journal of Human Rights, Culture and Legal System, 1.3 (2021)

Yusuf, Maulana, 'Model Rasio Pertumbuhan (MRP) Sebagai Salah Satu Alat Analisis Alternatif Dalam Perencanaan Wilayah Dan Kota Aplikasi Model: Wilayah Bangka-Belitung', Ekonomi Dan Keuangan Indonesias, 47.2 (1999) 